\title{
Ricostruire per riscoprire storie: la chiesa di S. Francesco a Piazza Palazzo all'Aquila
}

\author{
Stefano Brusaporci \\ Pamela Maiezza \\ Alessandra Tata \\ Mario Centofanti
}

Abstract

II contributo presenta la ricostruzione 3D della chiesa di S. Francesco all'Aquila, demolita nel I878. La modellazione viene realizzata sulla base di una approfondita ricerca documentale, dell'analisi critica dei disegni storici, dello studio del contesto. Un primo obiettivo del paper è lo studio di un monumento non più esistente, con l'impiego di visualizzazioni digitali per il racconto della storia di una importante porzione di ambito urbano, evidenziando le caratteristiche e di valori attraverso la comprensione dei processi di trasformazione che l'hanno condotto all'attuale configurazione. Obiettivo generale è sviluppare una riflessione teorico-metodologica sull'impiego della modellazione digitale tridimensionale quale metodo per lo studio di configurazioni architettoniche non più esistenti: prendendo le mosse dallo stato dell'arte, e con riferimento allo specifico caso di studio, vengono evidenziate potenzialità e problematiche in essere.

Parole chiave

beni architettonici, modellazione 3d, visual computing, comunicazione della storia.

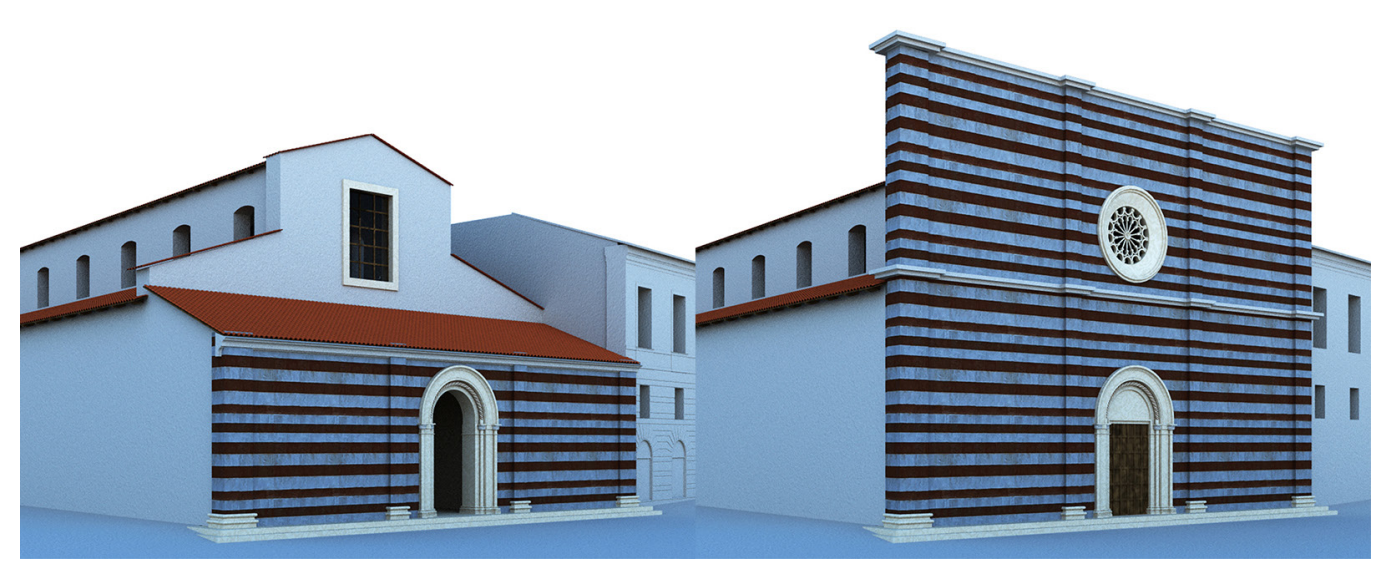




\section{Introduzione}

La chiesa di S. Francesco all'Aquila sorgeva su piazza Palazzo, fronteggiando la sede del governo civile, in posizione preminente nella definizione architettonica dello spazio urbano. Nel 1878 ebbero avvio i lavori di demolizione, per la realizzazione dell'isolato del Liceo-Convitto-Biblioteca-Camera di Commercio, in corrispondenza di un isolato della massima centralità urbana, all'intersezione degli assi ordinatori del tessuto urbano, secondo una volontà di rinnovo della città storica, con l'allargamento delle sezioni stradali e l'introduzione di una nuova tipologia con portici. Senza entrare nel merito delle vicende del nuovo progetto, che ha condotto all'assetto attuale, caratterizzato da importanti caratteri architettonici e urbanistici [Centofanti 2002], il presente contributo propone la ricostruzione digitale della scomparsa chiesa di S. Francesco, della quale oggi si è persa la memoria. L'obiettivo principale è il ricorso alla modellazione 3D come metodo di studio per l'analisi dei valori storici e architettonici [l].

Fig. I. L'attuale configurazione del sito dove sorgeva la chiesa, con i portici dell'isolato del Liceo-ConvittoBiblioteca-Camera di Commercio. Immagine fotografica e modello 3D.
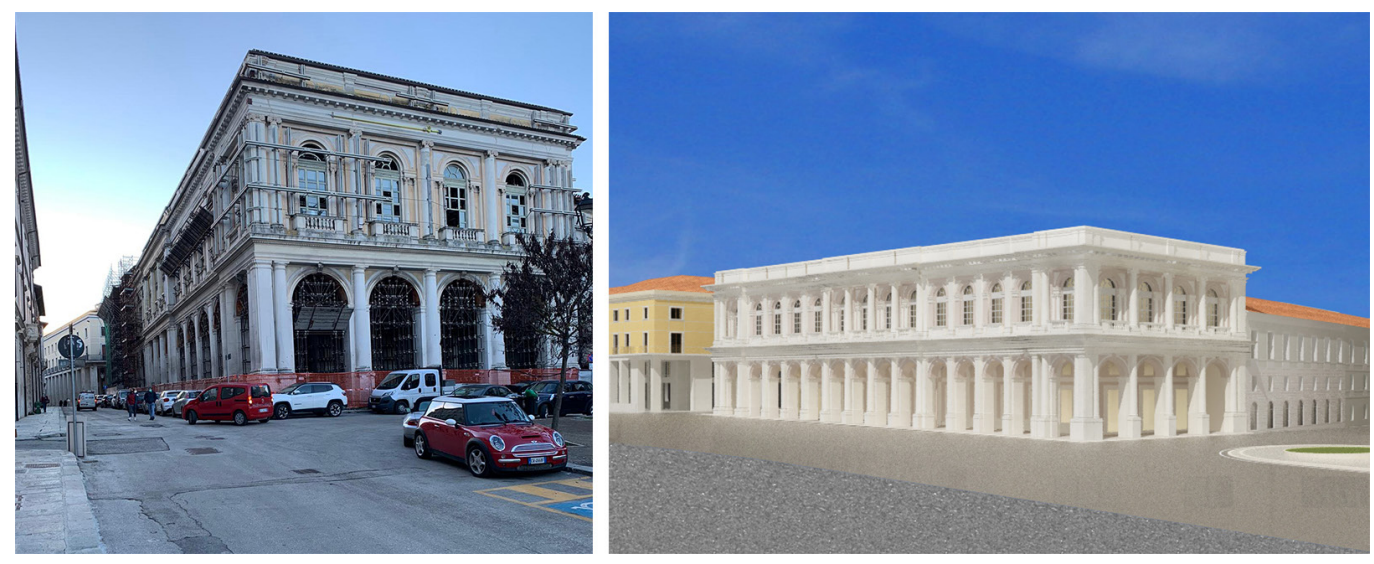

\section{La chiesa di S. Francesco}

L'insediamento francescano in questa zona centrale è presente sin dalla fondazione della città nel XIII secolo. Colpita gravemente dai terremoti del XIV secolo, la chiesa è ricostruita a tre navate; e al $X V$ secolo è ascrivibile una facciata bicolore. Danneggiata nuovamente dal terremoto del I703, tra il I 705 e il I 722 è rinnovata, assumendo l'ultima sua configurazione prima della demolizione nell'ultimo quarto del XIX secolo [Chiodi I988, Bartolini Salimbeni 1993, pp. 45-48; Centofanti 2002]. Presso l'Archivio dell'Accademia del Disegno di Firenze, sono conservati i disegni datati 1877 al rilievo della chiesa e del convento, ante trasformazione, realizzati a china su lucido telato in scala 1:200, e redatti dall'Ing. Pietro Giusti per I'Ufficio Tecnico Provinciale, in tavole con dim. 880×550 mm per le piante, e dim. 9I 0×570 per le sezioni [2]. Per il presente studio sono di specifico interesse la TAV. 3 "Pianta pianterreno", la TAV. 5 "Pianta piano primo", la TAVV. 6-7 raffigurante, tra le altre, la "Sezione sulla linea AB" longitudinale, e la "Sezione EF" trasversale. Inoltre, le carte della città dell'Aquila di Antonio Vandi del 1753 e di Vincenzo di Carlo del I 858 riportano la pianta del S. Francesco. Ulteriore documento di interesse è il "Gonfalone" di Giovanni Paolo Cardone del I579, conservato al Museo Nazionale d'Abruzzo, che offre una immagine con un livello di dettaglio particolarmente definito.

Sul piano spaziale e figurativo, la chiesa di S. Francesco costituiva la conclusione dellimportante asse di via Roma e fronteggiava sulla piazza il palazzo di Margherita D'Austria sede della municipalità aquilana. L'impianto della chiesa settecentesca è a tre navate. Le dimensioni a filo interno della chiesa sono di circa 25 metri in lunghezza è di 53 metri in larghezza; navata centrale larga 8 metri alta I 6,5 alla volta; navate laterali larghe 6 metri e alte 9; altezza 
Fig. 2. Rilievo della pianta della chiesa (1877).

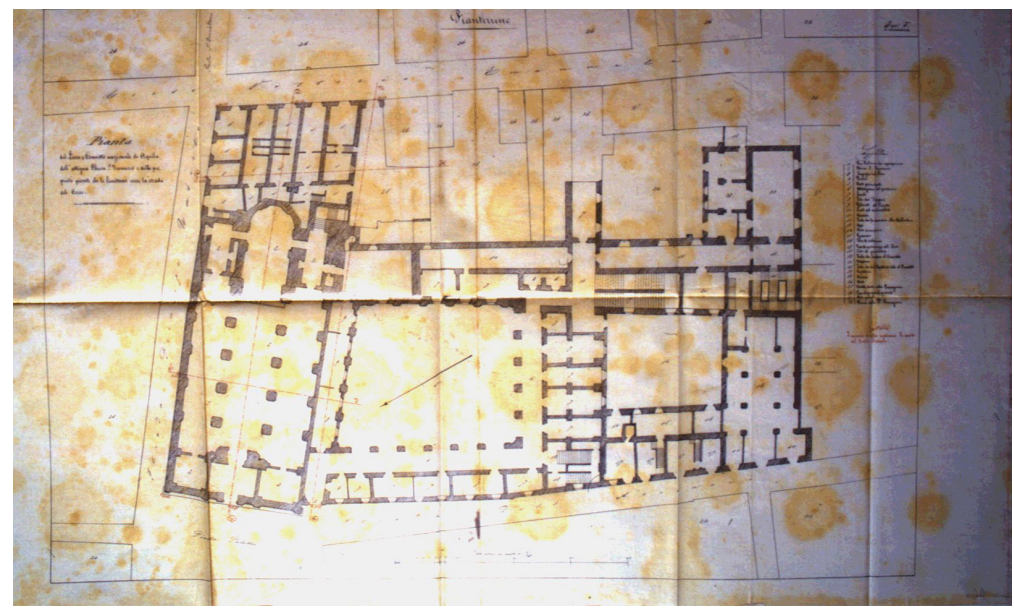

al colmo del tetto è 19 metri. In corrispondenza in navata centrale si apre un profondo vano absidale, probabilmente aggiunto nella seconda metà del XVIII secolo, atteso che non figura nella pianta del Vandi del 1753, e in quella del Di Carlo del 1858 è a semicerchio. La navata centrale è coperta con volta a tutto sesto lunettata per la presenza delle finestre laterali, mentre le navate laterali più basse, sono coperte da volte a vela. La sezione trasversale da conto della soluzione architettonica connessa con la simmetria della chiesa sulla asse longitudinale. II muro laterale destro infatti ha uno spessore ridotto rispetto a quello sinistro. Le navate laterali sono però identiche nelle dimensioni nella configurazione architettonica del modulo spaziale coperto a volta a vela. Cambia la dimensione del pilastro che porta figurativamente gli archi di imposta della vela, paraste come leggere articolazioni della parete sinistra, veri e propri pilastri sporgenti dal filo muro a destra.

Dalla sezione longitudinale appare evidente la soluzione di facciata con esonartece, vestibolo centrale e cappelle laterali, coperto uno spiovente. Non risolvibile invece il problema della morfologia della facciata in assenza di rilievi di prospetto documenti fotografici e della sua posizione che sembrerebbe arretrata rispetto a quella a coronamento orizzontale che si legge nel cinquecentesco gonfalone.
Fig. 3. Sezioni storiche sincroniche redatte sulla base del rilievo dello stato attuale, relative alla configurazione del sito e del contesto al XVIII e al XX secolo.

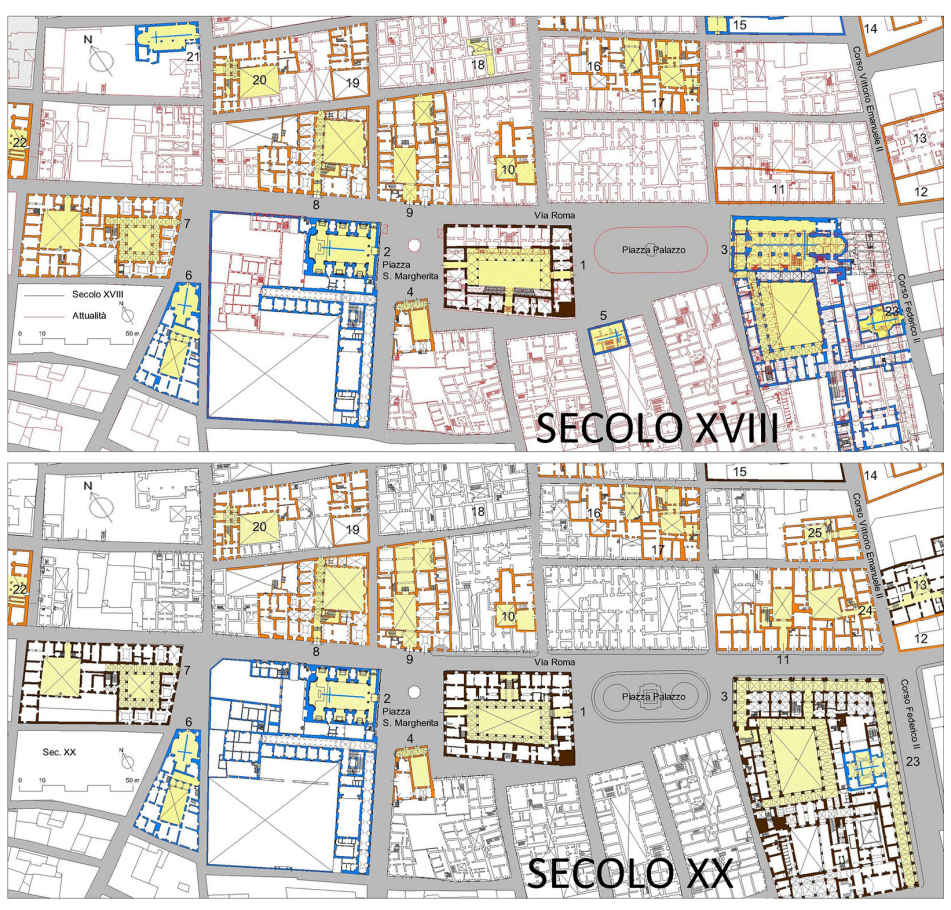


Fig. 4. Lettura ed interpretazione dei disegni storici di rilievo: pianta, sezione longitudinale e sezion trasversale.

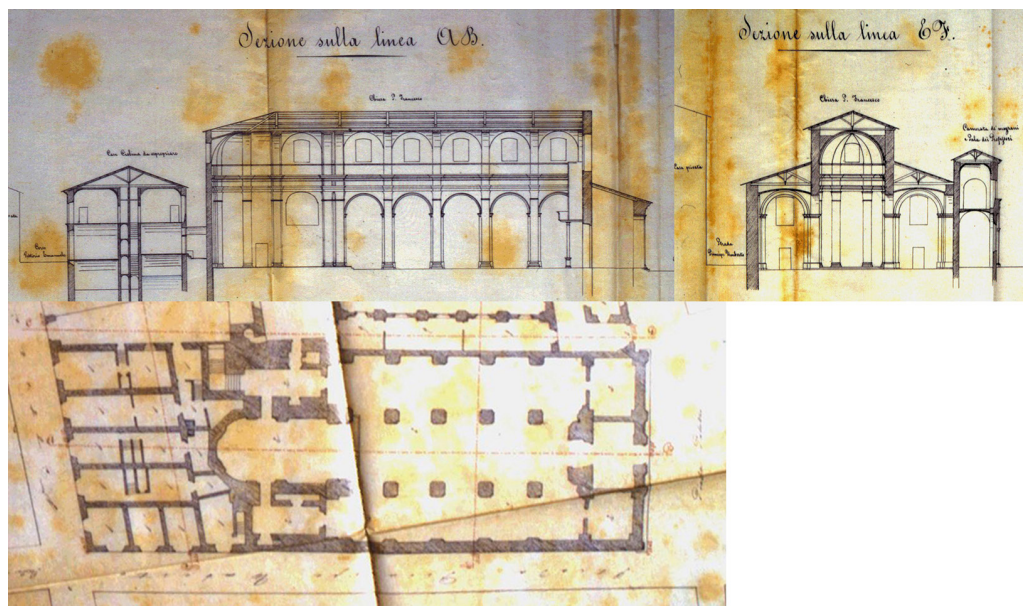

\section{Modellazione come metodologia}

Con lo sviluppo e diffusione delle tecnologie di modellazione digitale tridimensionale, per prima l'archeologia ha sperimentato gli ambiti della virtualità per la visualizzazione dei reperti e della ricostruzione di configurazioni non più esistenti [Forte, Siliotti 1996], e conseguentemente ha sviluppato riflessioni in merito alle potenzialità offerte da tale metodologia [Frischer 2008]. Proprio dal campo dell'archeologia sono nate la Carta di Londra [2009] e i Principi di Siviglia [20।2]. La prima, di valenza generale e interdisciplinare, vuole "stabilire i principi per l'uso dei metodi e dei risultati di visualizzazione digitale nella ricerca e nella comunicazione relativa ai beni culturale per: Fornire un caposaldo che abbia un ampio riconoscimento fra gli interessati; Promuovere il rigore tecnico e intellettuale nella visualizzazione digitale dei beni culturali; Assicurare che i procedimenti e i risultati della visualizzazione digitale possano essere capiti e valutati dagli utenti; Fornire autorevolezza scientifica alla visualizzazione digitale nello studio, nell'interpretazione e nella gestione dei beni culturali; Assicurare che siano stabilite e applicate strategie di accessibilità e sostenibilità; Offrire una solida base d'appoggio sul quale le comunità impegnate nel settore possano costruire linee guida più dettagliate a implementazione della Carta di Londra" [London Charter 2009, p. 4]. In accordo con principio della "Implementazione", seguono i "Principi di Siviglia" che propongono linee guida per l'archeologia. Di particolare importanza è il concetto di 'trasparenza':"All computer-based visualization must be essentially transparent, i.e. testable by other researchers or professionals, since the validity, and therefore the scope, of the conclusions produced by such visualization will depend largely on the ability of others to confirm or refute the results obtained" [Seville Principles 201 I, p. 8]. In tal senso i 'paradati' sono intesi come sorta di 'scholia', cioè di annotazioni e glosse che dovrebbero accompagnare le procedure di modellazione e visualizzazione per esplicitare le scelte critiche dello studioso
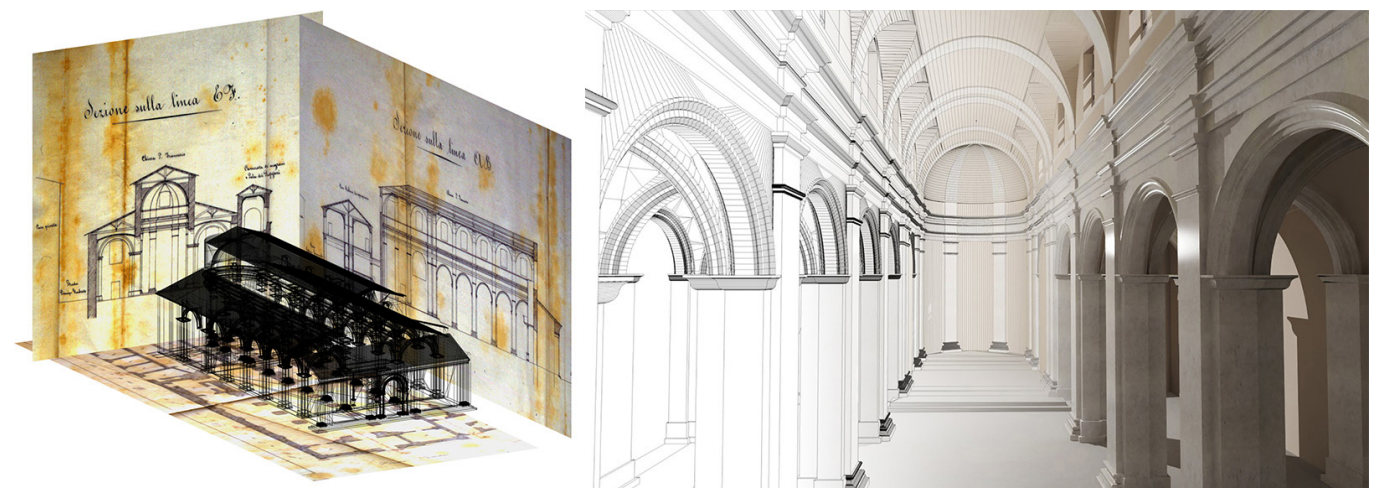
[Bentkowska-Kafel, Denard, Baker 20 I2]. In parallelo, il tema del digital heritage negli anni ha assunto risvolti sempre più importanti [Stone 1999; Ronchi 2009; Cameron, Kenderdine $2010 ;$ Ch'ng, Gaffney, Chapman 2013].

Gli studiosi di architettura, e in particolare gli studiosi della rappresentazione dell'architettura, avvezzi all'impiego del disegno e della modellazione (in primo luogo maquette), e il cui lavoro è incentrato su di una disciplina che pone al centro dell'approccio teorico-metodologico il ricorso a modelli restitutivi-interpretativi, hanno da subito fatto riferimento alla computer graphics, quale approccio per lo sviluppo di modelli interpretativi in grado di favorire nuove esperienze percettive, in grado di approfondire aspetti architettonici altrimenti solo mediati da rappresentazioni bidimensionali. Molteplici sono gli studi sviluppati negli ultimi anni [Docci 2007; Maggio, Villa 2008; Albisinni, De Carlo 20I I; Apollonio 20 I2; Marsiglia 20I3; Franchina, Maggio, Vattano 20 I5; Mangione, Ribichini, Terragni 2015 ; Sdegno 20 I5; Spallone 20 I5; Centofanti et al. 20 I7; Giordano, Huffman 20 I8; Maggio 20 I9; Maiezza 2020].

Per molti versi, l'esperienza di ricostruzione di architetture non realizzate o non più esistenti si rifa alla tradizione della cosiddetta 'analisi grafica', dove la rappresentazione 2D e 3D è intesa come strumento di studio dell'architettura stessa [Brusaporci 20। 8].

Certamente numerose sono le differenze tra l'ambito archeologico e quello dell'architettura, in ordine agli approcci metodologici, agli interessi specifici, alle strategie di rappresentazione, alle caratteristiche dei beni rappresentati, ultimo ma non ultimo, alle fonti documentarie, dalle quali discendono importanti conseguenze in ordine al livello di più o meno spinto di
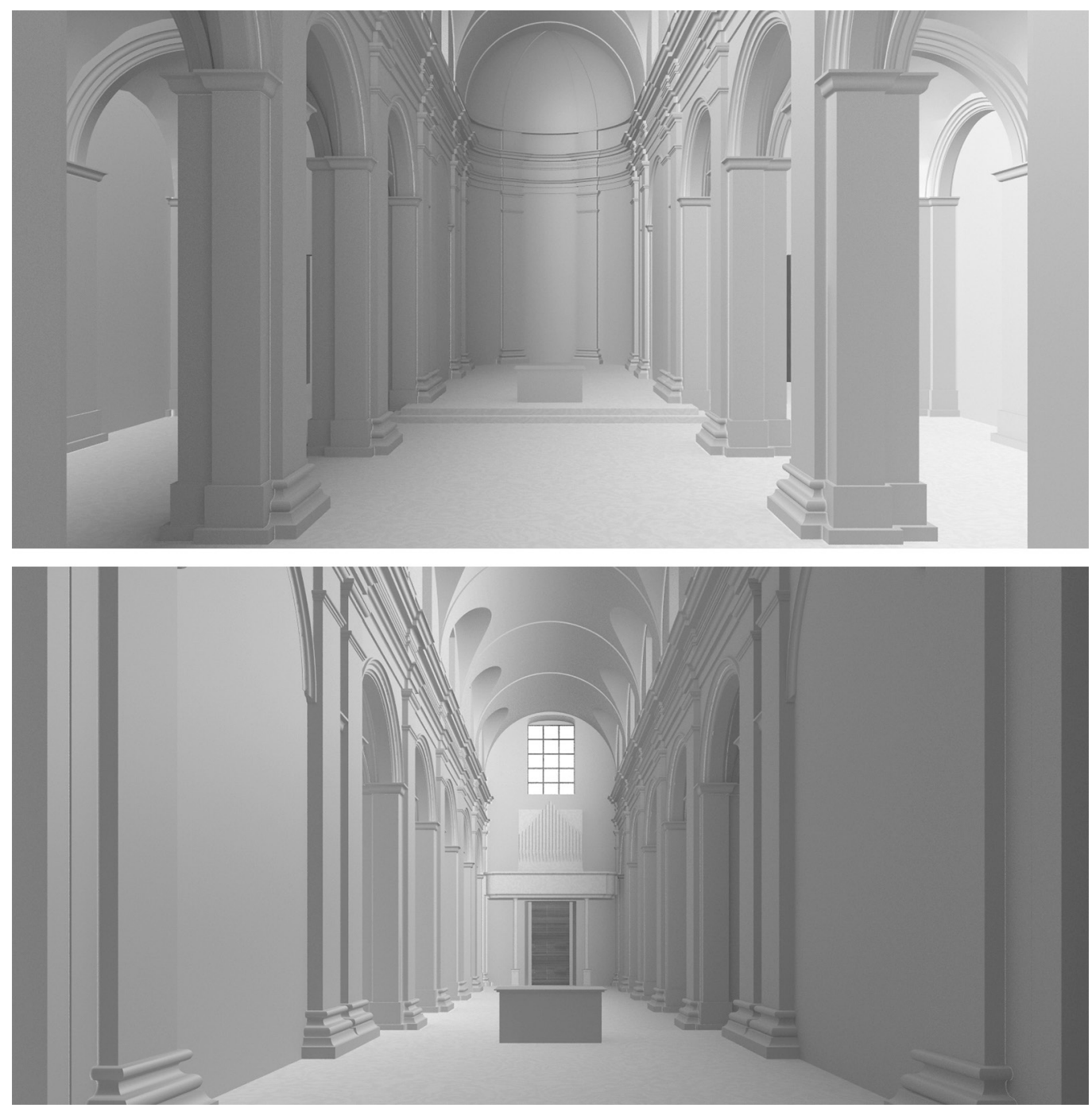
interpretazione. Infatti, differenti possono essere i campi di applicazione e di interesse: configurazioni del passato di edifici o brani della città storica fortemente modificati, architetture non più esistenti, edifici solo progettati. Anche lo spettro temporale varia dall'antichità all'architettura moderna e contemporanea. In particolare, la disponibilità di documenti d'archivio, di progetto o anche di cantiere, con scritti ma soprattutto grafici, quali disegni storici - di rilievo ovvero di progetto - carte, disegni di paesaggio, ma anche immagini fotografiche, offrono importati riferimenti che richiedono un approccio che rimanda all'ambito del visuale stesso. In ogni caso tali documenti a loro volta richiedono uno studio storico-critico preliminare. Non di minore importanza, nel caso di ricostruzioni che traggono riferimento dall'esistente, la necessità di incardinare le ricostruzioni su di un processo di rilevamento. Inoltre il passaggio da rappresentazioni discrete bidimensionali (piante, prospetti, sezioni) al continuum tridimensionale del modello 3D moltiplica i gradi di indeterminatezza.

Altro tema è quello di una opportuna distinzione tra istanze relative dalla modellazione geometrica e problematiche di texturizzazione e renderizzazione del modello. Ulteriori questioni discendono da: frequente non univocità tra le informazioni provenienti da diverse fonti; complessità nella diacronia dei processi di trasformazione e differente grado di informazione; differenza tra scala di rappresentazione dei documenti grafici, tra loro, e il livello di dettaglio richiesto al modello.

In conclusione, l'impiego di modelli 3D per lo studio dell'architettura configura un approccio euristico, assimilabile a percorsi di visual computing, dove la visualizzazione del modello favorisce la comprensione di fenomeni complessi, e lo sviluppo e validazione di ipotesi interpretative [Brusaporci 2015].

Fig. 7. Foto-inserimento delle ricostruzioni digitali della chiesa nel contesto, con viste dalla fronteggiante torre del Palazzo di Città e foto storica con l'assetto della piazza a inizio Novecento. (rendering A. Ruggieri) [3]
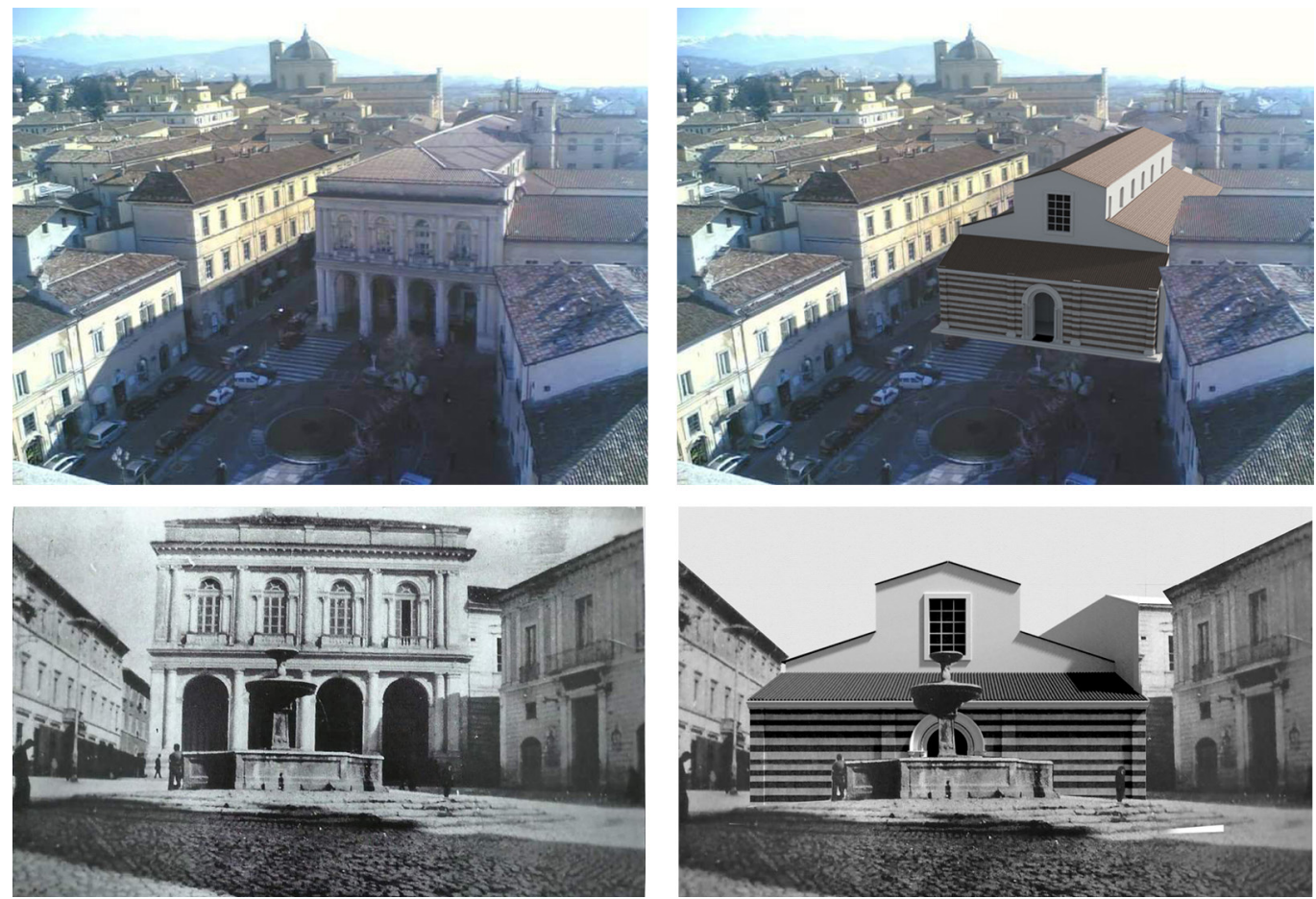

\section{Dalle fonti al modello}

Per la modellazione della chiesa di S. Francesco, il lavoro ha preso le mosse dalla ricognizione dello stato di fatto, seppur profondamente alterato rispetto alla fase storica oggetto di studio, così che solo alcuni elementi del contesto all'oggi sono ancora riscontrabili rispetto alla preesistenza, tra i quali il chiostro e l'antico campanile del convento, e il profilo di alcuni isolati. In parallelo si è proceduto con lo studio archivistico e bibliografico. Centrale è lo studio dei documenti storici, sulla base dei quali è stata condotta la ricostruzione della posizione 
Fig. 8. Gonfalone (Giovanni Paolo Cardone, 1579) con immagine della città dell'Aquila al XVI secolo, e particolare con la chiesa di S. Francesco. E possibile osservare la facciata a coronamento orizzontale. della chiesa e quindi la modellazione 3D. Sulla base della configurazione attuale, i disegni storici sono stati rimessi in scala. Facendo riferimento alla pianta del piano terra, sono stati vettorializzati ridisegnandoli in 2D. In questa fase, gli aspetti critici hanno riguardato l'interpretazione dei segni grafici, ovvero di informazioni presenti sugli elaborati.

Successivamente è stata sviluppata la modellazione 3D, che ha posto questioni in ordine alla 'trasposizione' e 'interpolazione' delle informazioni nel continuum tridimensionale. La "trasposizione" ha riguardato una opportuna restituzione spaziale di elementi rappresentati in scala 1:200 nei grafici di rilievo, con la conseguente definizione del livello di dettaglio del modello 3D. Aspetto di particolare criticità, è relativo all' "interpolazione" delle superfici nello spazio, così da richiedere la definizione geometrica di elementi per i quali non sono presenti sufficienti informazioni a riguardo. Se la tipologia delle volte può essere definita con sufficiente sicurezza a partire dai disegni, al contrario poco può dirsi del prospetto, e sui suoi elementi, in quanto è assente il rilievo della facciata e non sono disponibili immagini fotografiche d'epoca. É documentata la presenza di un portico, così come può essere desunta la presenza di lesene, ma nulla è dato sapersi sul coronamento di facciata o sulla geometria del portale o del finestrone.

Conseguentemente si è proceduto a sviluppare ipotesi interpretative dei processi di trasformazione dell'edificio nel tempo, che traggono origine dallo studio della documentazione storica e, in particolare, dall'osservazione degli spessori murari - troppo importanti per un portico -. Secondo il Gonfalone, al XVI secolo, la chiesa di S. Francesco presentava una facciata a coronamento orizzontale, in corrispondenza del fronte esterno del portico. Pertanto, si suppone che tale facciata possa essere crollata nella parte alta in occasione del sisma del 1703, e ricostruita arretrata in corrispondenza della prima campata. La parte inferiore della vecchia facciata, non crollata, sarebbe stata reimpiegata per realizzare il portico. Infine, è nota la presenza di un rivestimento in pietra policromo, successivamente alla demolizione reimpiegato per l'attuale fontana in piazza Regina Margherita. Dalle considerazioni fatte, è discesa la scelta di sviluppare anche la ricostruzione 3D della facciata nella configurazione al $\mathrm{XVI}$ secolo, e per i dettagli architettonici, si è fatto riferimenti a elementi interpretati secondo analogie formali e tipologiche.
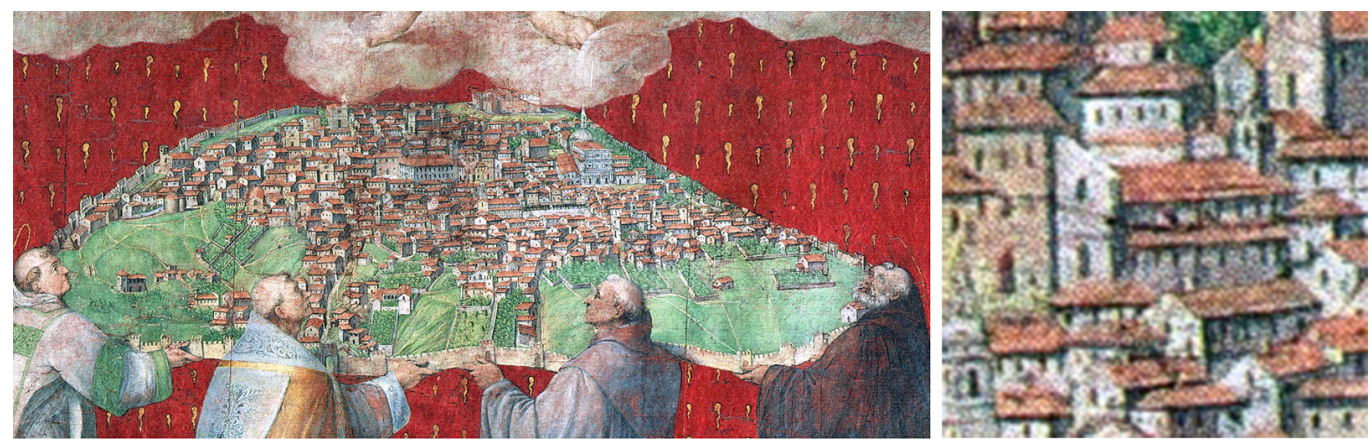

\section{Conclusioni}

Non ci si vuole soffermare su specifiche scelte interpretative o restitutive condotte in sede di modellazione, che certamente possono essere oggetto di discussione critica.

Invece si ritiene opportuno delineare alcune considerazioni di natura metodologica.

In primo luogo, appaiono evidenti questioni in ordine alla 'trasparenza scientifica', cioè alla rappresentazione e comunicazione delle scelte effettuate, i riferimenti alle fonti di diversa natura, le citazioni di natura comparativa e tipologica per quegli elementi per i quali i documenti non offrono indicazioni, nella assoluta mancanza di una normazione operativa.

Secondo aspetto riguarda il pericolo posto dalla forza visuale delle immagini di sintesi, che potrebbe indurre a una intrinseca valutazione estetica, fine a sé stessa, facendo perdere di vista il fine scientifico dell'attività, cioè la ricostruzione del passato per lo studio della storia 
Fig. 9. Modellazione digitale delle ipotesi della facciata della chiesa al $X X$ secolo, e al XVI secolo con foto-inserimento ne contesto attuale. del costruito e quindi comprendere le dinamiche che hanno condotto alla configurazione attuale, per sviscerare i valori architettonici e urbani della città storica [Spagnesi 1984]. Questo pericolo può essere ancora maggiore quando le immagini vengono rivolte a un pubblico di non esperti, e in questo caso appare necessario accompagnare l'attività di comunicazione con una adeguata presentazione e disseminazione. II rischio è quello di realizzare non modelli 'diacronici' della realtà che ci circonda, ma modelli "allocronici”, autoreferenziali, che rinviano a un ideale passato, non riferito all'attualità.

Ma come scriveva Lèvy, la "virtualità" può essere declinata nel senso etimologico proprio del termine: virtù, forza, potenza, cioè il modello digitale può offrire molteplici possibilità [Lèvy 1995]. Pertanto, gli stessi aspetti critici testimoniamo la forza di una metodologia, quella della ricostruzione 3D, che trova nella dimensione euristica della modellazione spaziale e nella percezione immersiva di multiple visualizzazioni, la vera intrinseca potenzialità. Infine, tenendo conto delle precedenti raccomandazioni, sulla base del modello restitutivo 3D, è possibile sviluppare progetti di comunicazione e riscoperta della storia di un monumento scomparso e di un luogo centrale della città.
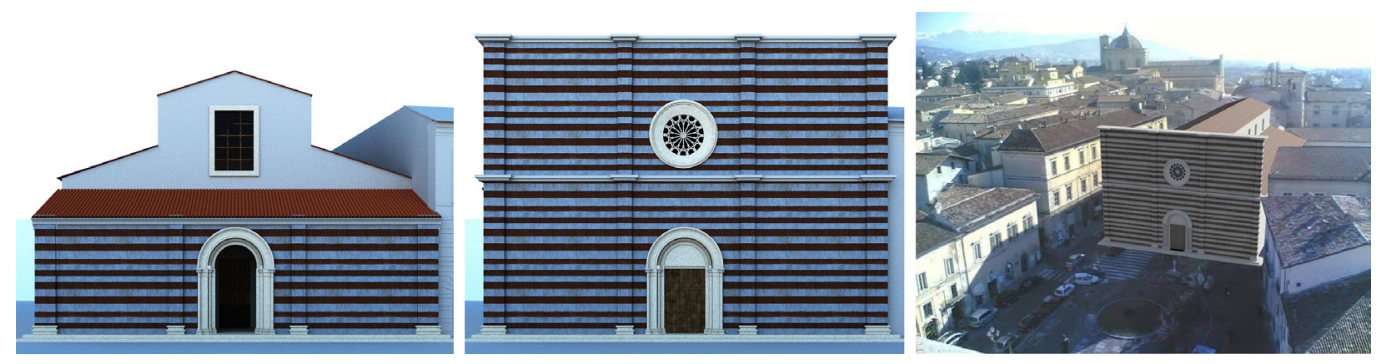

Note

[I] || presente contributo è stato concepito congiuntamente dagli autori. Tuttavia, i paragrafi possono essere attributi come segue: S. Brusaporci è autore di "Introduzione" "e "Conclusioni"; M. Centofanti di "La chiesa di S. Francesco"; P. Maiezza di "Modellazione come metodologia"; A. Tata di "Dalle fonti al modello".

[2] Archivio dell'Accademia del Disegno Firenze, "Atti |876- |877". Presso lo stesso archivio sono presenti anche la planimetria generale, la pianta dei piani sotterranei, la pianta del secondo piano, la sezione trasversale del convento, e delle case che sorgevano sul retro della chiesa. Un rilievo del convento del 1816 (?) è conservato presso l'Archivio di Stato dell'Aquila, Fondo Intendenza, serie I, cat. XIV, busta 4284 B, fasc. 4. Per uno studio di questi disegni cfr. Centofanti (2002). II riferimento a un altro rilievo della pianta della chiesa è in Bartolini Salimbeni (1993), p. 47.

[3] I foto-inserimenti sono rielaborazioni su immagini dal repository ju terramutu.

\section{Riferimenti bibliografici}

Albisinni P., De Carlo L. (a cura di). (201 I). Architettura. Disegno. Modello. Roma: Gangemi editore.

Apollonio F. I. (2012). Architettura in 3D. Milano: Bruno Mondadori.

Bartolini Salimbeni L. (1993). Architettura francescana in Abruzzo. In / Saggi di Opus, n. 2.

Bentkowska-Kafel A., Denard H., Baker, D. (Eds.) (20I2). Paradata and Transparency in Virtual Heritage. Farnham: Ashgate Publishing.

Brusaporci S. (20 I 5). On Visual Computing for Architectural Heritage. In S. Brusaporci (Ed.). Handbook of Research on Emerging Digital Tools for Architectural Surveying, Modeling, and Representation, vol. I, pp. 94- I 23. Hershey PA: IGI Global.

Brusaporci S. (2018). Graphical Analysis 2.0: Digital Representation for Understanding and Communication of Architecture. In E. Castaño Perea, E. Echeverria Valiente (Eds.). Architectural Draughtsmanship. From Analog to Digital Narratives, pp. 53 I -543. Cham: Springer.

Cameron F., Kenderdine S. (Eds.) (2010). Theorizing digital cultural heritage: a critical discourse. Cambridge, MA: MIT Press.

Centofanti M. (2002). Nuove architetture per la città moderna. In A. Clementi (Ed.). Un palazzo una città, pp.67-I 37. L'Aquila: Camera di Commercio Industria Artigianato e Agricoltura dell'Aquila.

Centofanti M. et al. (2017). Integrated Survey and Three-Dimensional Modeling for the Historical-Critical Study of Modern Architecture. The Colonia "IX Maggio" ( 1934- 1937) by Ettore Rossi. In C. Gambardella (Ed.). World Heritage and Degradation Smart Design, Planning and Technologies, pp. 1029-1036. Napoli: La scuola di Pitagora. 
Chiodi M. (1988). Le 170 chiese di L'Aquila dal '200 al '900. L'Aquila: Editrice Futura.

Ch'ng E., Gaffney V., Chapman H. (Eds.) (2013). Visual Heritage in the Digital Age. London: Springer.

Docci M. (2007). The unbuilt Vatican Basilica. The project by Antonio da Sangallo. In Disegnare. Idee immagini, 34, pp. 24-35.

Forte M., Siliotti A. (Eds.) (1996). Virtual Archaeology. Re-creating Ancient Words. New York: Harry N. Abrams.

Franchina A., Maggio F.,Vattano S. (20 I5). Female Architecture: Unbuilt Digital Archive. In S. Brusaporci (Ed.). Handbook of Research on Emerging Digital Tools for Architectural Surveying, Modeling, and Representation, pp. 5 I0-549. Hershey, PA : IGI GLOBAL.

Frischer B. (2008). From digital illustration to digital heuristic. In B.D. Frischer (Ed.). Beyond illustration: 2d and 3d Digital Technologies As Tool for Discovery in Archaeology, pp. v-xxii. Oxford: British Archaeological Reports.

Giordano A., Huffman K. (Eds.) (20 I 8). Advanced Technologies for Historical Cities Visualization. In Disegnarecon, vol. I I, n. 2 I .

Lèvy P. (1995). Qu'est-ce que le virtuel?. Paris: Editions La Dècouverte.

London Charter (2009): <https://www.londoncharter.org/> (consultato il 28 gennaio 202I).

Maggio F. (2019). Graphic Transcriptions: Le Corbusier and the Bologna enigma. In A. Luigini, C. Panciroli (Eds.). Img Journal 01/2019 Manifesto, pp. 184-199. Alghero: Publica.

Maggio F., Villa M. (2008). Architettura demolita. Palermo: Edizioni Caracol.

Maiezza P. (2020). Aquila Moderna. Progetti e interventi nella prima metà del XX secolo. Alghero: Publica.

Mangione F., Ribichini L., Terragni A. (Eds.) (2015). Giuseppe Terragni a Roma. Roma: Prospettive Edizioni.

Marsiglia N. (Ed.) (20I3). La ricostruzione filologico congetturale dell'architettura. Palermo: Grafill.

Maiezza, Aquila Moderna

Ronchi A. M. (2009). eCulture: Cultural Content in the Digital Age. Berlin Heidelberg: Springer-Verlag.

Sdegno A. (Ed.) (20I5). Le Corbusier reloaded. Disegni, modelli, video. Trieste: EUT Edizioni Università di Trieste.

Seville Principles (20 I I): <http://smartheritage.com/seville-principles/seville-principles> (consultato il 28 gennaio 202 I).

Spagnesi G. (1984). Autonomia della Storia dell'architettura. In G. Spagnesi (Ed.). Storia e restauro dell'architettura, pp. 7- I0. Roma: Istituto della Enciclopedia Italiana Treccani.

Spallone R. (20I5). Digital Reconstruction of Demolished Architectural Masterpieces, 3D Modeling and Animation:The Case Study of Turin Horse-Racing by Mollino. In S. Brusaporci (Ed.). Handbook of Research on Emerging Digital Tools for Architectural Surveying, Modeling, and Representation, pp. 476-509. Hershey, PA: IGI Global

Stone R. J. (1999).Virtual heritage. In UNESCO World Heritage Magazine, November, pp. I8-20.

\section{Autori}

Stefano Brusaporci, Università degli Studi dell'Aquila, stefano.brusaporci@univaq.it

Pamela Maiezza, Università degli Studi dell'Aquila, pamela.maiezza@univaq.it

Alessandra Tata, Università degli Studi dell'Aquila, alessandra.tata@graduate.univaq.it

Mario Centofanti, Università degli Studi dell'Aquila, mario.centofanti@univaq.it

Per citare questo capitolo: Brusaporci Stefano, Maiezza Pamela, Tata Alessandra, Centofanti Mario (2021). Ricostruire per riscoprire storie: la chiesa di S. Francesco a Piazza Palazzo all'Aquila/Rebuilding to rediscover stories: the Church of S. Francesco in Piazza Palazzo, L'Aquila. In Arena A., Arena M., Mediati D., Raffa P. (a cura di). Connettere. Un disegno per annodare e tessere. Linguaggi Distanze Tecnologie. Atti del $42^{\circ}$ Convegno Internazionale dei Docenti delle Discipline della Rappresentazione/Connecting. Drawing for weaving relationship. Languages Distances Technologies. Proceedings of the $42^{\text {th }}$ International Conference of Representation Disciplines Teachers. Milano: FrancoAngeli, pp. I $397-1414$. 


\title{
Rebuilding to Rediscover Stories: the Church of S. Francesco in Piazza Palazzo, L'Aquila
}

\author{
Stefano Brusaporci \\ Pamela Maiezza \\ Alessandra Tata \\ Mario Centofanti
}

Abstract

The paper presents the 3D reconstruction of the church of S. Francesco in L'Aquila city, demolished in 1878. Modeling is carried out on the basis of in-depth documental research, a critical analysis of historical drawings, and a study of the context. First aim is the study of a monument that no longer exists, with the use of computer-based visualizations to for the storytelling of an important portion of the urban environment, highlighting the characteristics and values through the understanding of the transformation processes that led to the current configuration. The general aim is to develop a theoretical-methodological reflection on the use of three-dimensional digital modeling as a method for the study of architectural configurations that no longer exist: starting from the state of the art, and with reference to the case study, the paper points out potentialities and issues.

Keywords

architectural heritage, 3D Modeling, visual computing, historical storytelling.

Demolished church of St. Francesco in L'Aquila: digital visualizations of the reconstructive

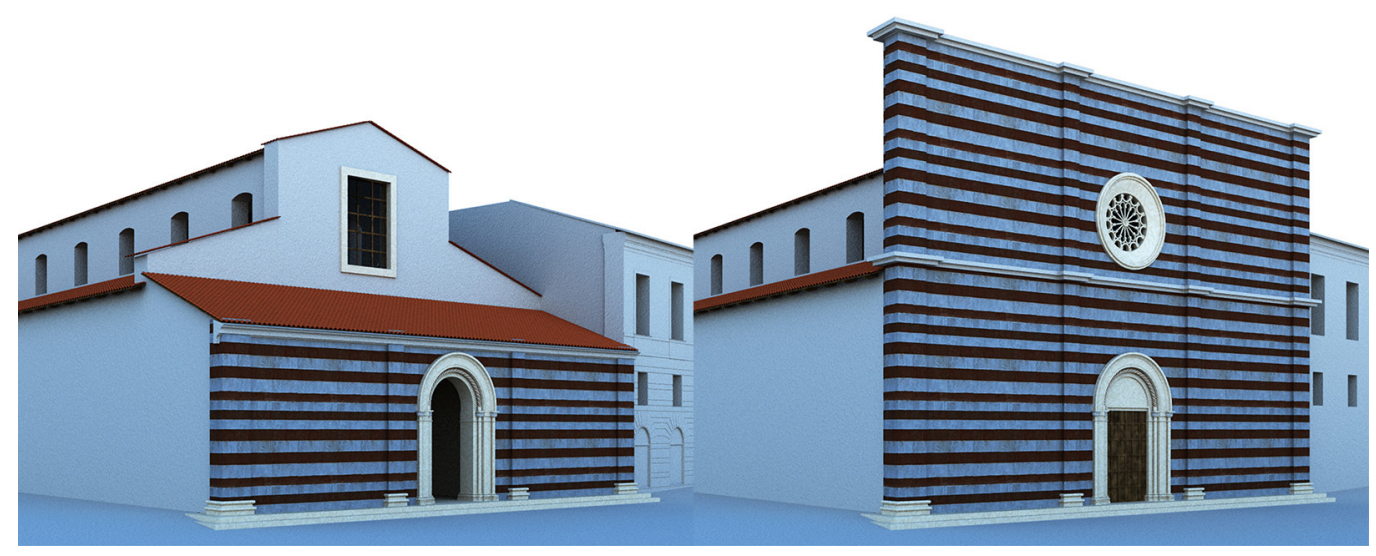




\section{Introduction}

The church of S. Francesco in L'Aquila was in Piazza Palazzo, facing the seat of the civil government, in a prominent position for the architectural definition of the urban space. In 1878, demolition work began, for the construction of the block of the Lyceum-Boarding School-Library-Chamber of Commerce, in correspondence with a block in urban central position, at the intersection of the ordering axes of the urban fabric, according to a desire for renewal of the historic city, with the widening of the road sections and the introduction of a new building typology with arcades. Without going into the merits of the events of the new project, which led to the current structure, characterized by important architectural and urban characteristics [Centofanti 2002], the paper presents the digital reconstruction of the disappeared church of S. Francesco, of which today the memory has been lost. The main aim is the use of 3D modelling as a study method for the analysis of historical and architectural values [I].
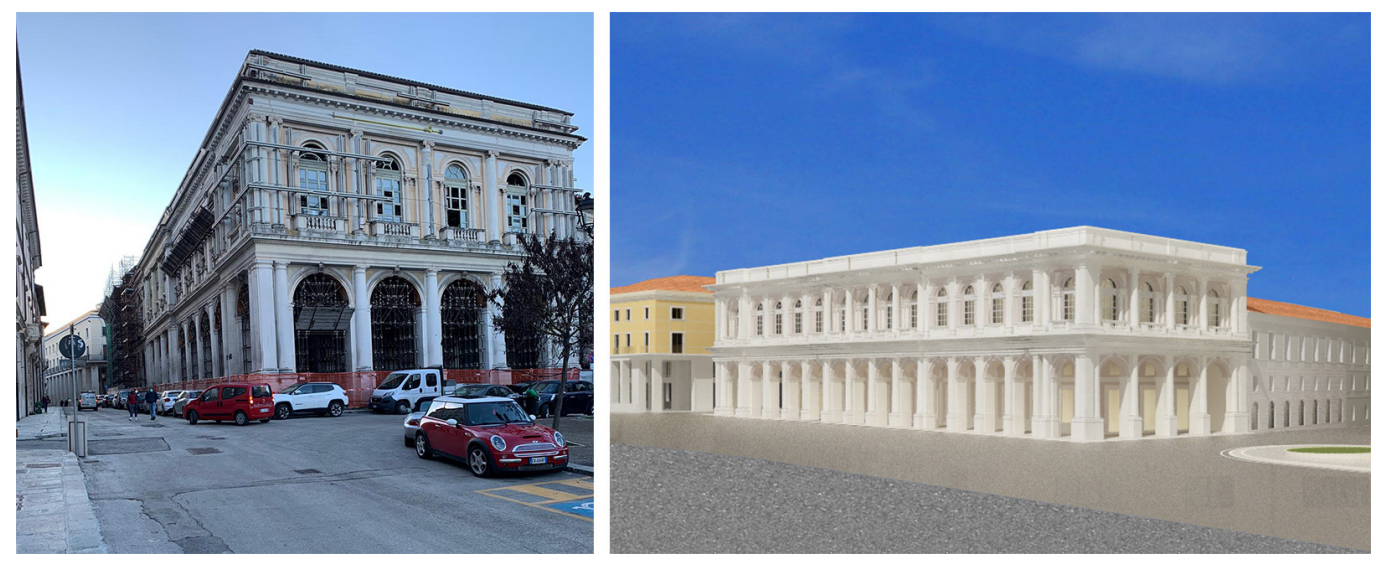

\section{The Church of S. Francesco}

The Franciscan settlement in this central area has existed since the founding of the city in the I3th century. Severely affected by the earthquakes of the fourteenth century, the church is rebuilt with three naves; and a two-tone façade can be attributed to the I5th century. Damaged again by the earthquake of 1703, between 1705 and 1722 it was renovated, taking on its last configuration before being demolished in the last quarter of the nineteenth century [Chiodi 1988, Bartolini Salimbeni 1993, pp. 45-48; Centofanti 2002]. In the Archive of the Accademia del Disegno in Florence, the surveying drawings of the church and of the convent, dated 1877 before transformation, are preserved, they are made in ink on glossy canvas at a scale of 1:200, and drawn up by Eng. Pietro Giusti for the Provincial Technical Office, in tables with dim. 880×550 mm for plants, and dim. 910×570 for the sections [2]. For the present study, TAV. 3 "Ground floor plan", TAV. 5 "First floor plan", TAVV. 6-7 representing, among others, the longitudinal "Section on line AB", and the transversal "Section EF" are of pivotal interest. In addition, the maps of the city by Antonio Vandi ( 1753 ) and by Vincenzo di Carlo (1858) show the plan of San Francesco. Another document of interest is the Gonfalone by Giovanni Paolo Cardone (1579), preserved in the National Museum of Abruzzo, which offers a view of the city with a particularly defined level of detail.

On the spatial and figurative level, the church of S. Francesco constituted the end of the important axis of Via Roma and faced on the square the palace of Margherita D'Austria, seat of the municipality of L'Aquila. The the eighteenth-century church has three naves. The internal dimensions of the church are about 25 meters in length and 53 meters in width; central nave 8 meters wide, 16.5 meters high, at the vault; lateral naves are 6 meters wide and 9 
Fig. 2. Architectural survey of the plan of the church (1877).

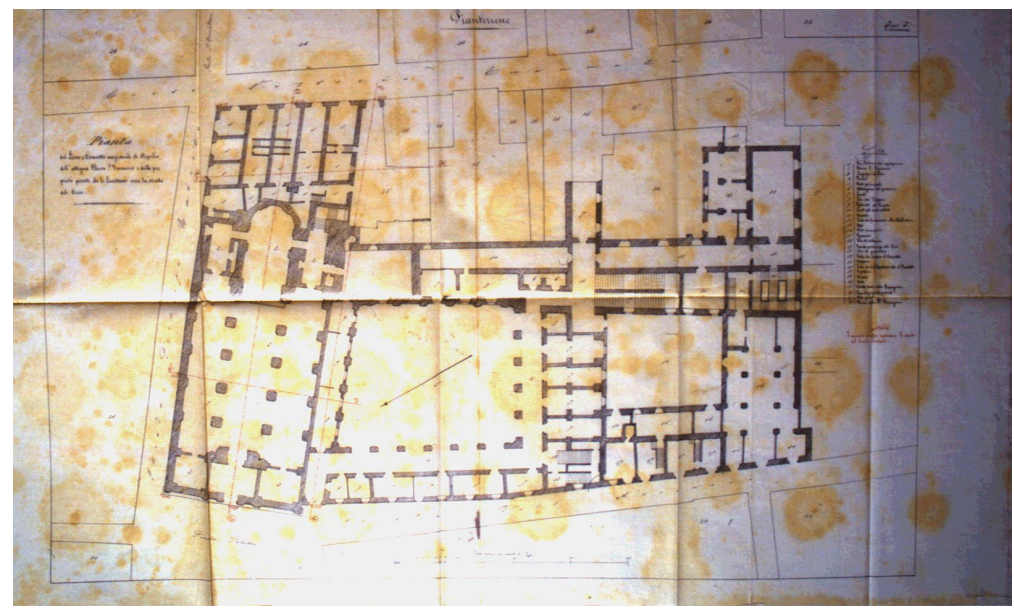

high and, the height at the top of the roof is 19 meters. In correspondence with the central nave opens a deep apse, probably added in the second half of the eighteenth century, since it does not appear in the Vandi plan of 1753, and in the one of Di Carlo of 1858 where it is semicircular. The central nave is covered with a round vault with lunettes for the side windows, while the lower aisles are covered by Bohemian vault. The cross section describes the architectural solution connected with the symmetry of the church on the longitudinal axis. In fact, the right-side wall has a reduced thickness compared to the left one.The aisles, however, are identical in size in the architectural configuration of the space module covered with a Bohemian vault. The size of the pillar that figuratively bears the arches of the sail changes, with pilasters like light articulations of the left wall, in fact pillars protruding from the right wall.

The longitudinal section shows the façade solution with exonarthex, central vestibule and side chapels, covered with a sloping roof. On the other hand, the problem of the morphology of the façade cannot be solved in the absence of elevation reliefs, photographic documents. Its position is back from the horizontal crowning façade that can be seen in the sixteenth century Gonfalone.
Fig. 3. Synchronic historical sections drawn up on the basis of the survey of the current state, relating to the configuration of the site and of the context in the $18^{\text {th }}$ and $20^{\text {th }}$ centuries.

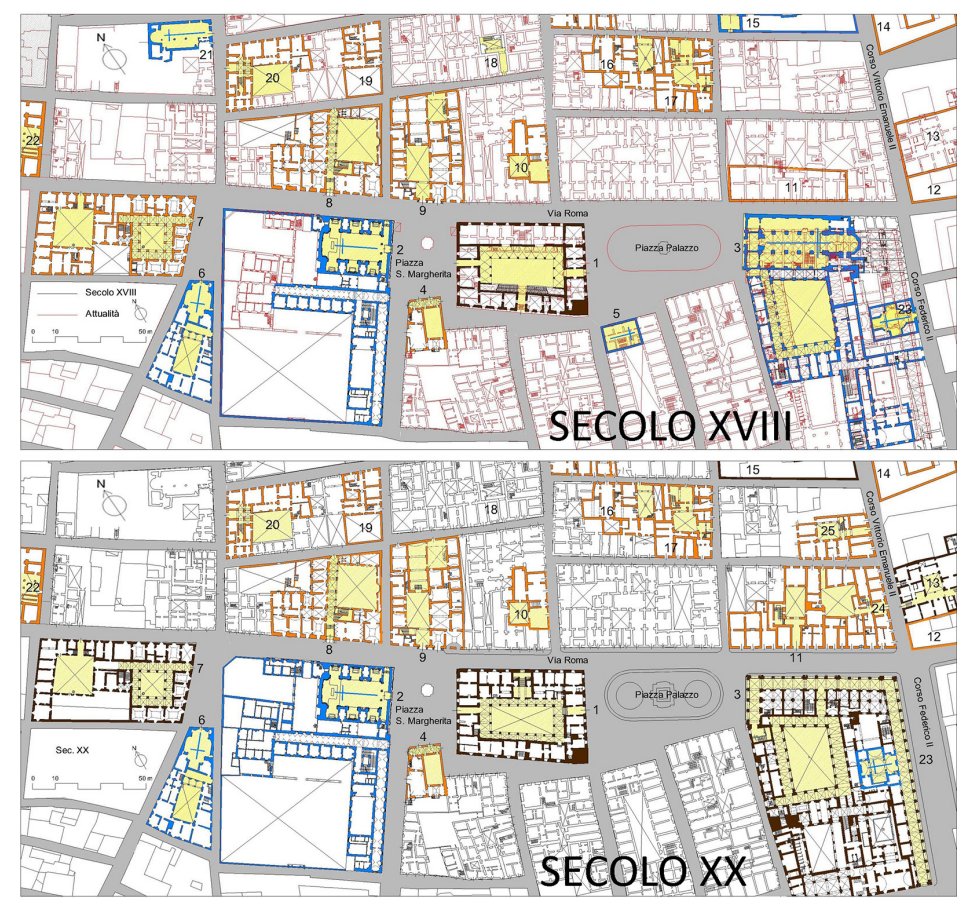


Fig. 4. Reading and interpretation of historical drawings: plan, longitudinal section and cross section.

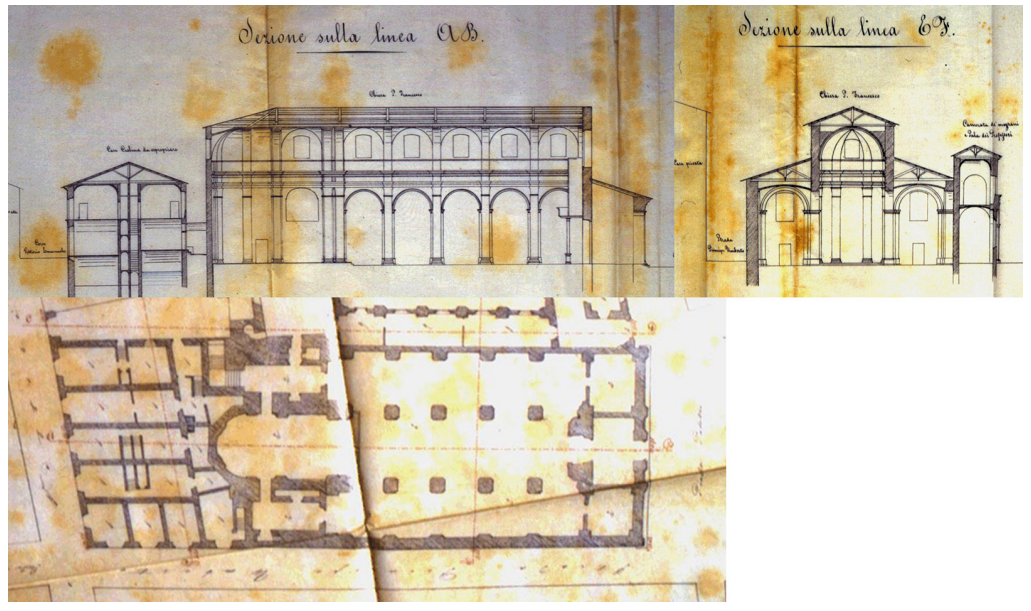

\section{Modelling as Methodology}

With the rise and diffusion of three-dimensional digital modeling technologies, archeology was the first to experiment with the areas of virtuality for the display of finds and the reconstruction of configurations no longer existing [Forte, Siliotti 1996], and consequently it developed reflections on the potential offered by this methodology [Frischer 2008]. The London Charter (2009) and the Principles of Seville (2012) were born precisely from the field of archaeology. The first, of general and interdisciplinary value, aims to "The London Charter seeks to establish principles for the use of computer-based visualisation methods and outcomes in the research and communication of cultural heritage in order to: Provide a benchmark having widespread recognition among stakeholders; Promote intellectual and technical rigour in digital heritage visualisation; Ensure that computer-based visualisation processes and outcomes can be properly understood and evaluated by users; Enable computer-based visualisation authoritatively to contribute to the study, interpretation and management of cultural heritage assets; Ensure access and sustainability strategies are determined and applied; Offer a robust foundation upon which communities of practice can build detailed London Charter Implementation Guidelines" [London Charter 2009, p. 4]. In accordance with the principle of 'Implementation', Principles of Seville proposes guidelines for archeology. Of particular importance is the concept of 'transparency': "All computer-based visualization must be essentially transparent, i.e. testable by other researchers or professionals, since the validity, and therefore the scope, of the conclusions produced by such visualization will depend largely on the ability of others to confirm or refute the results obtained" [Seville Principles 201 I, p. 8]. In this way, the 'paradates' are intended as a sort of "scholia", that is, annotations and glosses that should accompany the modeling and visualization procedures to make explicit the scholar's critical choices [Bentkowska-Kafel, Denard, Baker 20I2]. In
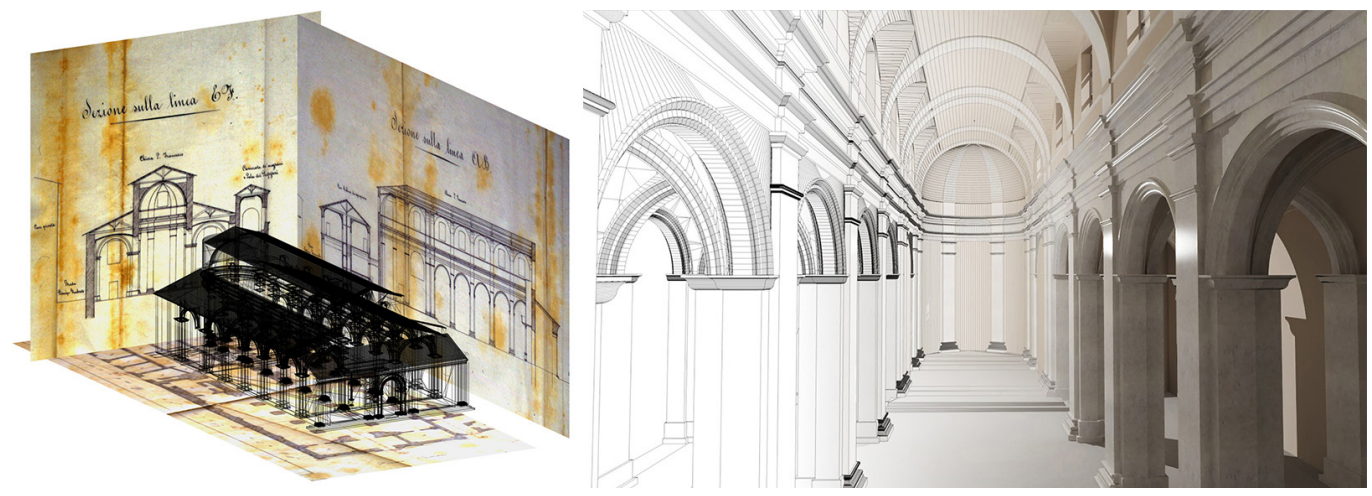
parallel, the theme of digital heritage has taken on increasingly important implications over the years [Stone 1999; Ronchi 2009; Cameron, Kenderdine 20 I0; Ch'ng, Gaffney, Chapman 20I3].

Architecture scholars, and in particular scholars of the representation of architecture, accustomed to the use of drawing and modeling (primarily maquettes), and whose work is centered on a discipline that places at the center of the theoretical - methodological approach the use of restitution-interpretative models, they immediately referred to computer graphics, as an approach for the development of interpretative models able to favor new perceptive experiences, able to deepen architectural aspects otherwise only mediated by two-dimensional representations. There are many studies developed in recent years [Docci 2007; Maggio,Villa 2008; Albisinni, De Carlo 201 I; Apollonio 20 I2; Marsiglia 20 I 3; Franchina, Maggio,Vattano 20 I5; Mangione, Ribichini, Terragni 20 I5; Sdegno 20I5; Spallone 20 I5; Centofanti et alii 20 17; Giordano, Huffman 20 I8; Maggio 20 I9; Maiezza 2020].

In many ways, the experience of reconstructing unrealized or no longer existing architectures refers to the tradition of the so-called 'graphic analysis', where 2D and 3D representation is intended as a tool for the study of architecture [Brusaporci 20 I8].

There are certainly numerous differences between the archaeological and architectural fields, in terms of methodological approaches, specific interests, representation strategies, the characteristics of the represented heritage, last but not least, the documentary sources, from which derives important consequences according to the more or less advanced level
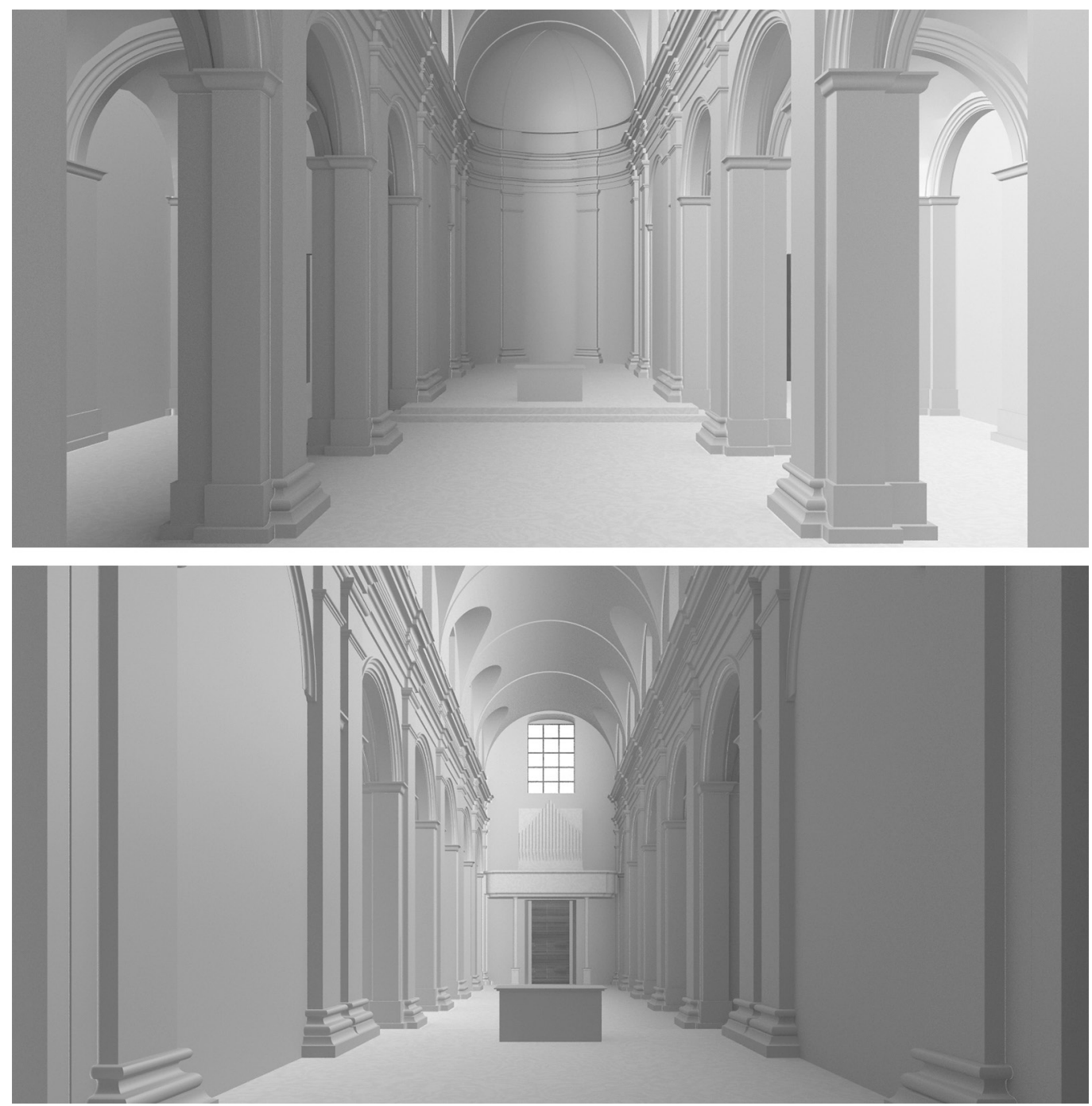
of interpretation. In fact, the fields of application and interest can be different: past configurations of buildings or parts of the historic city that have been heavily modified, architectures that no longer exist, only designed buildings. The temporal spectrum also varies from antiquity to modern and contemporary architecture. In particular, the availability of archival, project or even construction site documents, with writings but above all graphics, such as historical drawings -relief or project one- maps, landscape drawings, but also photographic images, offer important references that require an approach referred to visual analysis. In any case, these documents require a preliminary historical-critical study. In case of reconstructions referred to the existing, the need to hinge the reconstructions on a survey is very important.

Furthermore, the transition from discrete two-dimensional representations (plans, elevations, sections) to the three-dimensional continuum of the 3D model multiplies the degrees of indeterminacy.

Another theme is the appropriate distinction between instances posed by geometric modeling and problems of texturing and rendering of the model. Further issues arise from: frequent non-unicity between information from different sources; complexity in the diachronic transformation processes and different degree of information; differences in the scale of representation of graphic documents, between them, and with the level of detail of the model. In conclusion, the use of 3D models for the study of architecture configures a heuristic approach, similar to visual computing paths, where the visualization of the model favors the understanding of complex phenomena, and the development and validation of interpretative hypotheses [Brusaporci 20 I5].

Fig. 7. Photo-insertion of the digital reconstructions of the church in the context: view from the facing tower of the Town Hall and historical photo with the old square at the $20^{\text {th }}$ century (rendering A. Ruggieri) [3].
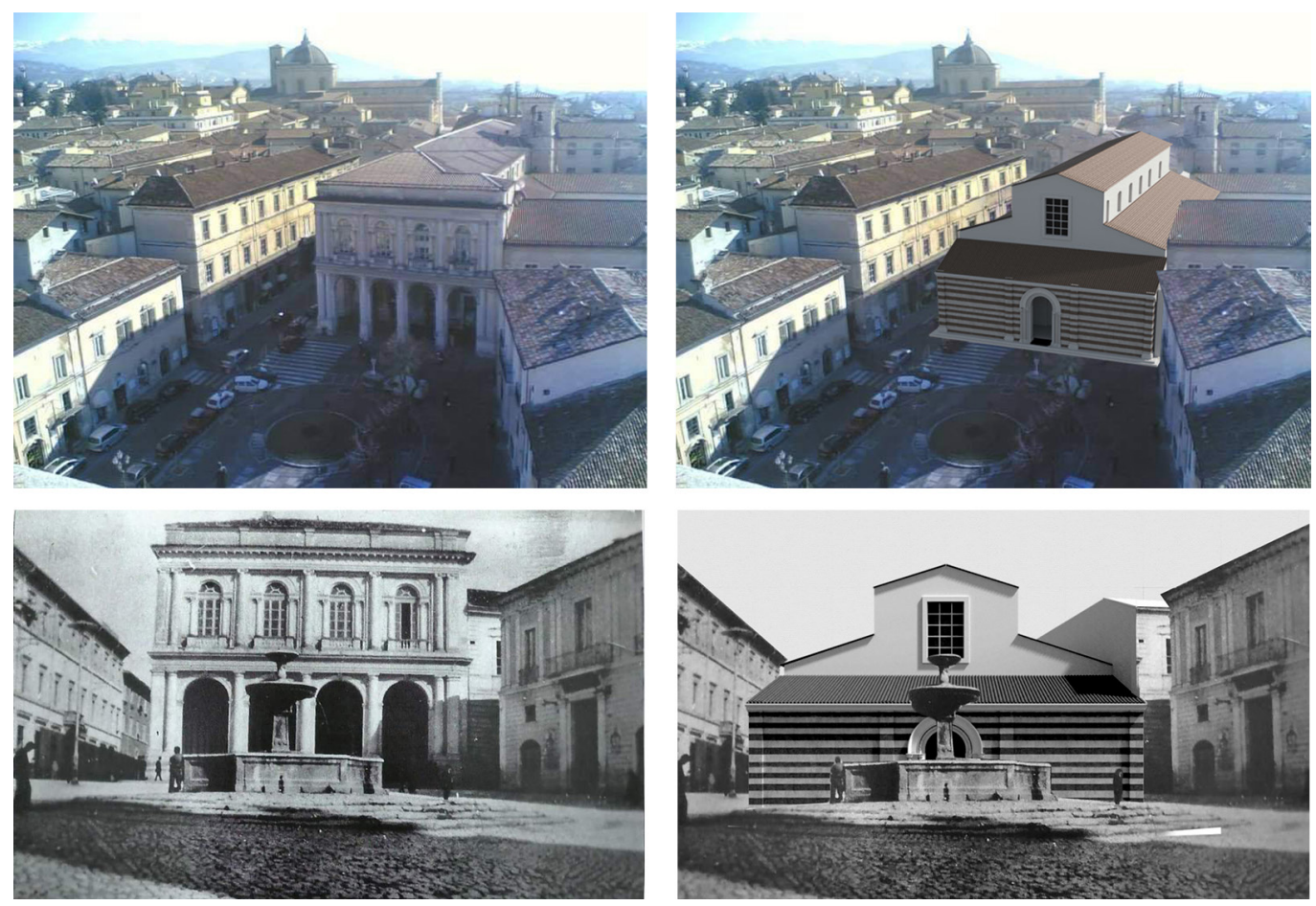

\section{From source to the model}

For the modeling of the church of S. Francesco, the work moved from the recognition of the present context, albeit profoundly altered with respect to the historical phase under study, so that only some elements of the environment today are still present with respect to the pre-existence, such as the cloister and the ancient bell tower of the convent, and the profile of some blocks. In parallel we developed the archival and bibliographic study. Central is the study of historical documents, on the basis of which the reconstruction of the position of 
the church and then the 3D modeling was conducted. Based on the still recognizable elements, the historical drawings have been re-scaled. Referring to the ground floor plan, they have been vectored by redesigning them in 2D. In this phase, the critical aspects have concerned the interpretation of the graphic signs, or of some information on the documents. Subsequently, 3D modeling has been developed; it raised questions regarding the 'transposition' and 'interpolation' of 2D information in the three-dimensional continuum. The 'transposition' involved the appropriate spatial restitution of elements represented in scale 1:200 in the survey graphs, with the consequent definition of the level of detail of the 3D model. The 'interpolation' of surfaces in the space has been a particularly critical aspect, so as to require the geometric definition of elements for which there is not enough information about it. If the type of vaults can be defined with sufficient certainty starting from the drawings, on the contrary little can be said about the main elevation, and on its elements, because the relief of the facade is absent and there are no old photographic images. The presence of a portico is documented, as the presence of pilasters, but nothing is known about the crowning of the façade or about the geometry of the portal or of the window.

Consequently, interpretative hypotheses of the transformation processes of the building over time have been developed, originated from the study of historical documentation and, in particular, from the observation of the wall thicknesses -too important for a portico-. According to the "Gonfalone", in the sixteenth century, the church of S. Francesco had a horizontal crowning facade, in correspondence of the external front of the portico. Therefore, it is assumed that this façade may have collapsed in the upper part during the earthquake of 1703 and rebuilt in correspondence with the first span. The lower part of the old façade, which had not collapsed, would have been reused to build the portico. Finally, the presence of a polychrome stone cladding is known, which was reused after the demolition to realize the current fountain in Piazza Regina Margherita. This led to the decision to model the 3D reconstruction of the 16th century configuration of the façade; for the architectural details, reference was made to elements interpreted according to formal and typological analogies.

Fig. 8. Gonfalone (Giovanni
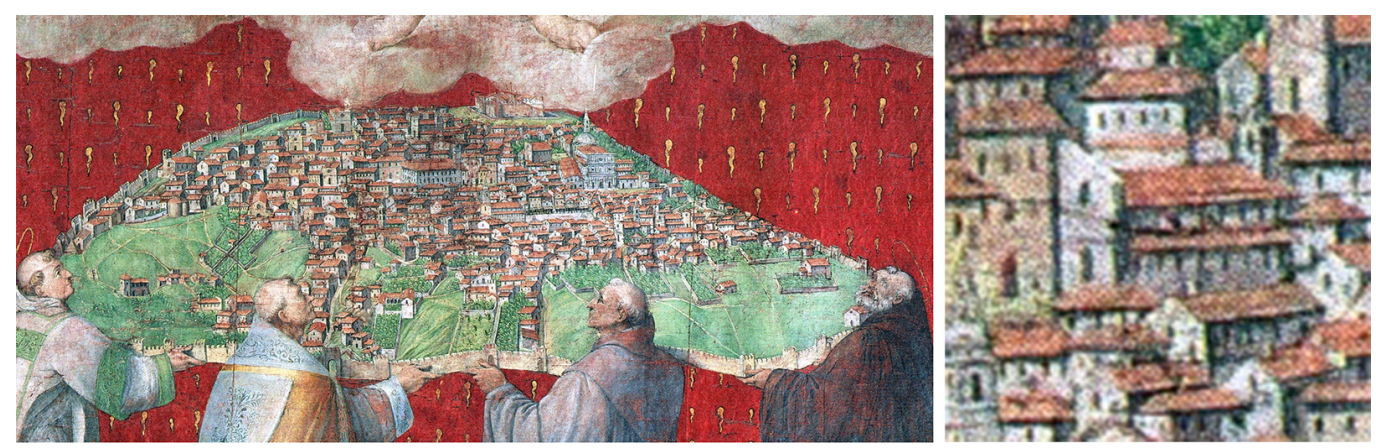

\section{Conclusions}

We do not want to dwell on specific interpretative or restitution choices made during the modelling phases, which certainly can be the subject of critical discussion. Instead, it is considered appropriate to outline some methodological considerations.

First of all, there are questions regarding the 'scientific transparency', that is, the representation and communication of the choices made, references to sources of different nature, citations of comparative and typological nature for those elements for which the documents offer no indications, in the absolute lack of operational standardization.

A second aspect concerns the danger posed by the visual strength of the synthetic images, which could lead to an intrinsic aesthetic evaluation, an end in itself, making the observer to lose sight of the scientific purpose of the modeling, that is the reconstruction of the past for 
Fig. 9. Digital modeling of the hypotheses of the facade of the church at the $20^{\text {th }}$ century, and in the $16^{\text {th }}$ century with photo-insertion in the current context. the study of the history of the built heritage and therefore for the understanding of the dynamics that led to the current configuration, to highlight the architectural and urban values of the historic city [Spagnesi 1984]. This danger can be even greater when the images are addressed to an audience of non-experts, and in this case it appears necessary to accompany the communication activity with adequate presentation and dissemination. The risk is the one of the creation of non-diachronic models of the reality that surrounds us, but "allochronic" models: self-referential models that allude to a ideal past, not related to actuality. As Lèvy said, "virtuality" can be declined in the etymological sense of the term: it is avirtue, strength, power, that is, the digital model can offer multiple possibilities [Lèvy 1995]. Therefore, the same critical aspects testify to the strength of a methodology, the one of 3D reconstruction, which finds its true intrinsic potential in the heuristic dimension of spatial modeling and in the immersive perception of multiple views. Finally, taking into account the previous recommendations, on the basis of the 3D restorative model, it is possible to develop communication and rediscovery projects of the history of a missing monument and of a central place in the city.
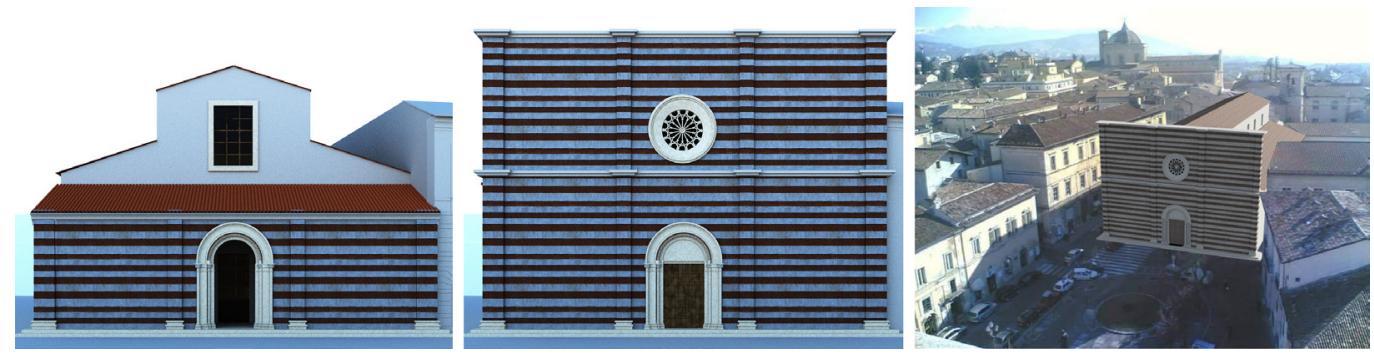

\section{Notes}

[I]The paper was conceived jointly by the authors. However, the paragraphs can be attributed as follows: S. Brusaporci is the author of "Introduction" and "Conclusion"; M. Centofanti of "The Church of S. Francesco"; P. Maiezza of "Modelling as Methodology"; A. Tata of "From source to the model".

[2] Archivio dell'Accademia del Disegno Firenze, "Atti I 876- I877". In the same archive there are also the general plan, the plan of the underground floors, the plan of the second floor, the cross section of the convent, and of the houses that stood at the back of the church. Another survey of the convent dated 1816 (?) is at l'Archivio di Stato dell'Aquila, Fondo Intendenza, serie I, cat. XIV, busta 4284 B, fasc. 4 (Centofanti 2002). The reference to another relief of the church plan is in Bartolini Salimbeni (1993), p. 47.

[3] The photo insertions are re-elaborations made on images from the repository Ju terramutu.

\section{References}

Albisinni P., De Carlo L. (a cura di). (20I I). Architettura. Disegno. Modello. Roma: Gangemi editore.

Apollonio F. I. (2012). Architettura in 3D. Milano: Bruno Mondadori.

Bartolini Salimbeni L. (1993). Architettura francescana in Abruzzo. In / Saggi di Opus, n. 2.

Bentkowska-Kafel A., Denard H., Baker, D. (Eds.) (20I2). Paradata and Transparency in Virtual Heritage. Farnham: Ashgate Publishing.

Brusaporci S. (20 I 5). On Visual Computing for Architectural Heritage. In S. Brusaporci (Ed.). Handbook of Research on Emerging Digital Tools for Architectural Surveying, Modeling, and Representation, vol. I, pp. 94- I 23. Hershey PA: IGI Global.

Brusaporci S. (2018). Graphical Analysis 2.0: Digital Representation for Understanding and Communication of Architecture. In E. Castaño Perea, E. Echeverria Valiente (Eds.). Architectural Draughtsmanship. From Analog to Digital Narratives, pp. 53 I-543. Cham: Springer.

Cameron F., Kenderdine S. (Eds.) (2010). Theorizing digital cultural heritage: a critical discourse. Cambridge, MA: MIT Press.

Centofanti M. (2002). Nuove architetture per la città moderna. In A. Clementi (Ed.). Un palazzo una città, pp.67- I 37. L'Aquila: Camera di Commercio Industria Artigianato e Agricoltura dell'Aquila.

Centofanti M. et al. (2017). Integrated Survey and Three-Dimensional Modeling for the Historical-Critical Study of Modern Architecture. The Colonia "IX Maggio" (1934-1937) by Ettore Rossi. In C. Gambardella (Ed.). World Heritage and Degradation Smart Design, Planning and Technologies, pp. 1029-1036. Napoli: La scuola di Pitagora. 
Chiodi M. (1988). Le 170 chiese di L'Aquila dal '200 al '900. L'Aquila: Editrice Futura.

Ch'ng E., Gaffney V., Chapman H. (Eds.) (2013). Visual Heritage in the Digital Age. London: Springer.

Docci M. (2007). The unbuilt Vatican Basilica. The project by Antonio da Sangallo. In Disegnare. Idee immagini, 34, pp. 24-35.

Forte M., Siliotti A. (Eds.) (1996). Virtual Archaeology. Re-creating Ancient Words. New York: Harry N. Abrams.

Franchina A., Maggio F.,Vattano S. (20 I5). Female Architecture: Unbuilt Digital Archive. In S. Brusaporci (Ed.). Handbook of Research on Emerging Digital Tools for Architectural Surveying, Modeling, and Representation, pp. 5 I0-549. Hershey, PA : IGI GLOBAL.

Frischer B. (2008). From digital illustration to digital heuristic. In B.D. Frischer (Ed.). Beyond illustration: 2d and 3d Digital Technologies As Tool for Discovery in Archaeology, pp. v-xxii. Oxford: British Archaeological Reports.

Giordano A., Huffman K. (Eds.) (20 I 8). Advanced Technologies for Historical Cities Visualization. In Disegnarecon, vol. I I, n. 2 I .

Lèvy P. (1995). Qu'est-ce que le virtuel?. Paris: Editions La Dècouverte.

London Charter (2009): <https://www.londoncharter.org/> (accessed 2021, January 28).

Maggio F. (2019). Graphic Transcriptions: Le Corbusier and the Bologna enigma. In A. Luigini, C. Panciroli (Eds.). Img Journal 01/2019 Manifesto, pp. 184-199. Alghero: Publica.

Maggio F., Villa M. (2008). Architettura demolita. Palermo: Edizioni Caracol.

Maiezza P. (2020). Aquila Moderna. Progetti e interventi nella prima metà del XX secolo. Alghero: Publica.

Mangione F., Ribichini L., Terragni A. (Eds.) (2015). Giuseppe Terragni a Roma. Roma: Prospettive Edizioni.

Marsiglia N. (Ed.) (20I3). La ricostruzione filologico congetturale dell'architettura. Palermo: Grafill.

Maiezza, Aquila Moderna

Ronchi A. M. (2009). eCulture: Cultural Content in the Digital Age. Berlin Heidelberg: Springer-Verlag.

Sdegno A. (Ed.) (20I5). Le Corbusier reloaded. Disegni, modelli, video. Trieste: EUT Edizioni Università di Trieste.

Seville Principles (20 I I): <http://smartheritage.com/seville-principles/seville-principles> (accessed 202 I, January 28).

Spagnesi G. (1984). Autonomia della Storia dell'architettura. In G. Spagnesi (Ed.). Storia e restauro dell'architettura, pp. 7-I0. Roma: Istituto della Enciclopedia Italiana Treccani.

Spallone R. (20I5). Digital Reconstruction of Demolished Architectural Masterpieces, 3D Modeling and Animation:The Case Study of Turin Horse-Racing by Mollino. In S. Brusaporci (Ed.). Handbook of Research on Emerging Digital Tools for Architectural Surveying, Modeling, and Representation, pp. 476-509. Hershey, PA: IGl Global

Stone R. J. (1999). Virtual heritage. In UNESCO World Heritage Magazine, November, pp. I 8-20.

\section{Authors}

Stefano Brusaporci, Università degli Studi dell'Aquila, stefano.brusaporci@univaq.it

Pamela Maiezza, Università degli Studi dell'Aquila, pamela.maiezza@univaq.it

Alessandra Tata, Università degli Studi dell'Aquila, alessandra.tata@graduate.univaq.it

Mario Centofanti, Università degli Studi dell'Aquila, mario.centofanti@univaq.it

To cite this chapter: Brusaporci Stefano, Maiezza Pamela, Tata Alessandra, Centofanti Mario (2021). Ricostruire per riscoprire storie: la chiesa di S. Francesco a Piazza Palazzo all'Aquila/Rebuilding to rediscover stories: the Church of S. Francesco in Piazza Palazzo, L'Aquila. In Arena A. Arena M., Mediati D. Raffa P. (a cura di). Connettere. Un disegno per annodare e tessere. Linguaggi Distanze Tecnologie. Atti del $42^{\circ}$ Convegno Internazionale dei Docenti delle Discipline della Rappresentazione/Connecting. Drawing for weaving relationship. Languages Distances Technologies. Proceedings of the $42^{\text {th }}$ International Conference of Representation Disciplines Teachers. Milano: FrancoAngeli, pp. I 397- I 4 I4. 